

















2017-06-30

\section{Methodology for the assessment of distributed propulsion configurations with boundary layer ingestion using the discretized miller approach}

\section{Valencia, Esteban}

Praise Worthy Prize

Esteban Valencia, Chengyuan Liu, Devaiah Nalianda, et al., Methodology for the assessment of distributed propulsion configurations with boundary layer ingestion using the discretized miller approach. International Review of Aerospace Engineering, Vol 10, No 3 (2017)

https://doi.org/10.15866/irease.v10i3.12404

Downloaded from Cranfield Library Services E-Repository 